\title{
マルチエージェントシミュレーションによるタク シー営業戦略の改善シナリオの提案
}

\section{Investigation of the Potential of Multi-Agent Traffic Simulations to Find Good Arrangement of Taxies}

\author{
金月 寛彰 \\ 株式会社富士通研究所 人工知能研究所 \\ Hiroaki Kingetsu \\ Fujitsu Laboratories \\ h.kingetsuljp.fujitsu.com \\ 服部 宏充 \\ 立命館大学 情報理工学部 \\ College of Information Science and Engineering, Ritsumeikan University \\ hatto@fc.ritsumei.ac.jp
}

keywords: multi-agent simulation, transportation, taxi, probe car

\begin{abstract}
Summary
In this paper, we describe a method to compute multiple improvement scenarios for Multi-Agent Simulation using parameter search by metaheuristic. Specifically, we try to construct multiple scenarios to acquire more customers by using modeling of taxi driver's behavior from probe car data. The main proposal of this paper is not to find an optimal solution but an approach to lead multiple suboptimal solutions. We construct a taxi agent model that can represent individual traffic behaviors and apply the model to urban traffic multi-agent simulation where general vehicles, bus, and taxis co-exist in the realistic road network of the city of Kyoto, Japan. Then, we try to construct multiple improvement scenarios concerning the sales strategy by multipoint local search method and clustering of parameters. The proposed method works usefully in the problem that the solution property with wide solution space is unknown. In addition, this method has scalability, and it is possible to obtain a better optimum solution by increasing the number of cluster calculators and increasing the number of searching points.
\end{abstract}

\section{1. は じめに}

マルチエージェントシミュレーション (MASim: MultiAgent Simulation) は, 複雑で大規模な社会システムを計 算機上で再現するミクロシミュレーションの一手法であ る. 個々の行動主体 (人間や車両, など) の行動を模擬し たエージェントモデルを構築し, 集積されたエージェン ト同士の創発現象により集団全体としての社会現象を再 現する.MASimによる交通分野への適用については，大 規模な交通施策の変更や導入を目的とした，シミュレー ションを用いた施策の事前評価などがあり, 多くの研究 者の注目を集めている.

交通シミュレーションの活用の一つとして, 現状の交 通流に関して改善シナリオを立案し, シミュレーション による都市交通の再現によりその適用結果を予測するも のがある、しかし，MASim を用いて，ユーザが改善の ための具体的なシナリオ案を作成するには, 対象地域に おける運転者の行動を精緻に分析し, 運転行動モデルを 構築したうえで, 膨大なパラメータと複雑な相互作用の 影響を考慮する必要がある，また，シナリオに対するシ
ミュレーション結果の算出とその検証といった従来のア プローチは，シミュレーションを実施する前に具体的な シナリオ案を確立していない場合には適用が難しい。そ こで本論文では，メタヒューリスティクスによるパラメー タ探索を利用して, 改善シナリオを複数導出する手法に ついて述べる. 本論文では, 例題としてタクシーの顧客 獲得に関する営業運転行動について扱う。ここでは, 観 測データから研究対象地域におけるタクシー運転者の特 徵的な営業行動に着目して分類し，それぞれの営業行動 を模擬した複数の類型のモデルを組み込んだエージェン トを用いる. タクシーの総数を固定した条件下で，各類 型に属するタクシーエージェントの台数を入力パラメー タとして与え, 全タクシーの顧客獲得回数の総計が多くな るように入力パラメータを変化させ，探索を行う. どの ような運転行動の類型の分布が顧客獲得回数を増やすた めには有利であるかを分析し，改善シナリオを導出する.

本論文の主たる提案は, 一つの最適解 (改善シナリオ) を導くのではなく, 複数の準最適解を導くアプローチに ある.これは，広大なパラメータを探索し最適解を算出 できたとしても，その最適解が現実として実社会に適用 
が難しいシナリオであれば，実践的とは言えないと著者 らは考えるためである．たとえば，ある局所的最適解が 大域的最適解に評価值として及ばなくとも，現実的に実 行しやすい改善シナリオであれば，局所的最適を導くシ ナリオを採用することも合理的な解決方法であると言え る. すなわち, 膨大な解空間からいくつかの有望な解 (改 善シナリオ）を絞り込み，ユーザ（ステークホルダ）に， 視覚的および数量的に理解しやすい形で複数の提案を行 える仕組みこそが，MASim を用いる利点の一つである と著者らは考える．本論文の目的は，一つの大域的最適 解を導くのではなく, 現状を改善しうる複数の準最適解 から，複数の改善シナリオを導くことにある．本論文で は，実データの分析に基づいて，特徵ある個々の運転者 の行動モデルを組み込んだエージェントを用いて, 複数 の改善シナリオを MASim によるパラメータ探索によっ て提案する.

著者らは, タクシー走行データの分析により, タクシー の営業行動に関する運転行動を分析・モデル化し，一般 車両やバスが混在する現状の環境を模擬したシミュレー ション上にて, タクシー運転者の営業行動の再現を試み ている.ここでは，その知見を用いて，京都市地域におけ るタクシーを対象に，大規模並列処理に適したパラメー タ探索手法を用いて，より多くの顧客獲得を目的とした 運転行動の改善シナリオの提案を試みる.

本論文の以降の構成を述べる．まず，2 章で関連研究 について紹介する．３章では，交通シミュレーションを 用いたパラメータ探索と提案手法の概要について述べる. 4 章では, タクシー運転者の行動の特性を組み込んだ行 動モデルとシミュレータ，およびパラメータ探索のため の計算環境について述べる. 最後に， 5 章で構築モデル を用いたシミュレーションを実施して得られたパラメー タに関して実験と考察について述べる。

\section{2. 関 連 研 究}

MASim を用いて, 交通に関する諸問題に対してアプ ローチを行った研究がこれまでに数多く行われている. 文 献 [小柴 14] では，社会システムの導入のために都市規 模で公共交通のシミュレーションを適用し, 網羅的探索 からシステムデザインの検討を行っている．一方，都市 規模での実問題を扱う適用には全探索が困難な場合もあ ることから，本論文ではヒューリスティック探索を適用 し，さらにユーザに複数のシナリオの提示をする目的か ら, 解の傾向が異なるような出力を行えることができる 手法を提案する.

タクシーは主要な公共交通機関の一つであり,これま でMASim を用いたタクシー営業行動に関する様々なシ ミュレーションが行われてきた. タクシーの走行データ を用いた分析として，文献 [Shen 17, Sun 16,Wu 17] があ り, これまでに様々な都市において研究が行われている.
これらの研究は, 特定の環境や気候において顧客の需要 予測など, 全タクシーに共通する営業行動の特徵につい て統計的な抽出・分析が行われている. タクシーは特定 のスケジュールによって走行が制御されるものではない ため, 顧客の需要やタクシー挙動の分析はより困難であ る. 典型的なタクシーの挙動の一つとして, タクシーを 電話やスマートフォンアプリから呼び出すことのできる 配車挙動がある. 配車タクシーに関する研究として, 文 献 [Bischoff 16] がある. また, 配車に限らずタクシー運 転者が顧客を拾う挙動をエージェントに組み込み, シミュ レーションを行ったものとして, 文献 [Cheng 11] がある. これらの研究では, 分析対象地域で観測されたデータに 基づき, 一様なルールに基づく営業を行うエージェント を用いて, タクシーエージェントが報酬を増加させる最 適行動を執った場合の効果についてシミュレーションを 行っている. 一方で, 本論文のアプローチは, 営業行動 についての個性を表現可能なモデルを用いて, 顧客獲得 回数を増やす運転行動の類型の分布の最適解を含む複数 の解候補群を導くことにある. 顧客の獲得数を目的関数 としてパラメータ探索を行い, シミュレーションが導き 出す結果を考察することで, MASim の実践的な有用性 を問う。

\section{3. パラメータ探索による改善シナリオの導出}

\section{$3 \cdot 1$ パラメータ探索の目的}

本稿でのシミュレーションの目的は, タクシーを例題 としたときに, 顧客の総獲得数を増加させる営業行動の シナリオを構築することである.ここでは, 観測データ の分析に基づく研究対象地域におけるタクシー運転者の 特徵的な営業行動に着目する. 各運転者がどの地域で顧 客を獲得する傾向があるのかに着目して分類し, それぞ れの営業行動を模擬した複数の類型のモデルを組み込ん だエージェントを用いる. シミュレーション内のタクシー の総数を固定したときに, 各類型に属するタクシーエー ジェントの各台数を入力パラメータとして与え, どのよ うな運転行動の類型の分布が顧客獲得に有利なのか解の 傾向を分析することで, 複数の解（改善シナリオ）を導 出する. 評価值は, シミュレーション時間内での全タク シーエージェントが顧客を獲得した数の総計（以下, 顧 客獲得回数）とし，これを最大化するようにパラメータ 探索を行う.

これまでに著者らは，プローブデータによるタクシー 運転者の営業行動の分析から, タクシー運転者の営業行 動に対して教師なし分類を行い, 営業行動の個性に着目 したエージェントのモデル化を行っている [金月 18]. ある 営業行動の類型に属する運転者群を運転者クラス $d$ とし たときに, 各運転者クラス $d$ に属するタクシーエージェン トの台数 $p_{d}$ を一つのパラメータとして, すべての運転者 クラスに対するエージェント台数を表現するパラメータ 
セット $P=\left\{p_{d 1}, p_{d 2}, \ldots\right\}$ を入力パラメータとしてシミュ レーションに与える. 営業行動の個性に着目したエージェ ントのモデルでは, 運転者の営業地域の嗜好を反映する ことが可能であるが, 従来のようなタクシー運転者の一 様な行動モデルでは, 実際には運転者が過去に行ったこ とがない地域での活動も, 営業行動の候補として同程度 に考慮されてしまう.すなわち，本モデルの適用は，現状 の経路情報や営業戦略を分析および再現したうえで, 現 状の営業行動に対する複数の改善方法をステークホルダ へ提案するという本論文のアプローチに従うものである.

\section{$3 \cdot 2$ 提案手法の概要}

パラメータ探索アルゴリズムとして，多点局所探索法 を用いる．本論文で扱う問題に対して，多点局所探索法 の利点は以下である.

・都市規模のエージェント数を用いた場合, 探索空間 が大きくなることから, 計算機処理に並列環境を用 いることを考える．多点方式は並列環境において実 装が容易であり，さらに，それぞれが独立したシミュ レーション計算環境に対しては導入がしやすく, 解 の収束経過が確認しやすい利点がある.

- 多点探索によって複数の局所的最適解の算出が可能 であり，それぞれの解について観察し，知見を得る という本論文の目的と合致する.

多点局所探索法は，次のような過程を経る.

(1) 任意数の探索点 $S_{n}(n=1,2,3 \ldots)$ の数だけ初期值 を任意に与え, 各点に関して初期評価值 $V$ を計算 する。

(2) 点 $S_{n}$ に紐付くパラメータセット $P$ の中から, 無 作為に取り出した二つのパラメータのうち，一つを 近傍幅 $\delta$ だけ増加させ，他方を近傍幅 $\delta$ だけ減少さ せるようにして近傍探索を行う。

(3) 点 $S_{n}$ に関して現在の評価值を計算し, 現在の評 価值 $V$ よりも大きな值であれば，評価值 $V$ を更新 する.

(4) 終了条件まで (2) と (3) を繰り返す.

最終的に, 類型の挙動を行うエージェント台数がどれ だけ存在するかを示すパラメータセットが探索点の数だ け得られる.これらのパラメータセットに対し, 顧客獲得 回数の多かった解候補について分析し, 改善シナリオを 導出する. 改善シナリオへの導出は, 以下の手順を辿る. i. 多点探索

各運転者クラスの挙動を振る舞うエージェントの数を パラメータとして，ランダムに与えた初期值から近傍幅 $\pm \delta$ の探索で解空間の特徵を探る. 多点探索のシステムの 概要を図 1 に示す. 多点探索は以下の計算の過程を辿る.

（1）実行ホストは探索点の数だけ初期值のパラメータ セットを用意し，シミュレーション実行環境フレー ムワークにキューを投げる.

(2) フレームワークは計算ノードに探索点のプロセス
を走らせる. シミュレーションプロセスが，多点探 索による $n$ 個の探索点の数だけ（並列）実行される. (3) 探索点プロセスは局所探索を開始する. トライア ルを $j$ 回繰り返し, パラメータセットを更新しつつ, 評価值を探索する。

（4）各トライアルでは共進化アルゴリズムに基づく経 路探索 [Balmer 09] を，センサスデータに近づく交 通流量となるまで $k$ 回（世代）繰り返される， $k$ 世 代での全エージェントの経路選択における評価值が 一つのトライアル内での評価值となる.

（5）すべてのプロセスが終了するまで繰り返す。一つ の探索点プロセス内で最大の評価值 $V$ が各プロセ ス内での解に相当する. 全探索点の数だけ解を得る. 全体のシミュレーションの実行回数は $n \times j \times k$ 回 となる。

一般車両とタクシーの目的地決定，および一般車両の 初期開始位置は，どの地域から出発し，どの地域へ目的 地として流動したかを表形式に数量を示した地域間 OD (Origin-Destination) 表のデータに基づく. 地域間 ODに ついては，信頼性のおけるデータとして京都市の調査デー タに従う。ただし，地域ごとの開始位置に関しては確率 的選択であるために，ランダムシードの影響を受けるが， 計算簡略化のために，探索時にはランダムシードを固定 する. ランダムネスが結果に与えうる影響については, 最 終的な解候補に対して分析を行う.

ii. パラメータセットのクラスタリング

多点探索により得られた局所的最適解の傾向を知るた めに，解に対してクラスタリングを行う。分類されたクラ スタのそれぞれから最大の評価值を持つパラメータセッ 卜を各クラスタの代表として選定して解候補とすること で，異なる傾向を示す複数の解候補が獲得可能となる.

iii. ファインチューニング

局所探索法の実装上では, 近傍幅 $\delta$ を更新の度に減少 させることが多い，本論文では，クラスタリングによっ て得られた解候補のパラメータセットに関して初期探索 より小さな近傍幅で探索し, 解のファインチューニング を行う.すなわち，クラスタリングによって得られた解 候補のパラメータセットを初期值として, 再度, 近傍幅 を小さくした多点局所探索法を適用し，最大の評価值を 算出する.

iv. パラメータセットの分析

解候補のパラメータセットの分析により, シミュレー ション上でどのような営業戦略を採るタクシーの分布が 効率的に顧客を拾うことができているかを観察する.

\section{4. タクシー運転者のモデル化と 大規模交通シミュレータ}

本論文で用いるタクシー運転者の運転行動モデルは, プローブデータの分析により営業行動を行う地域に個性 


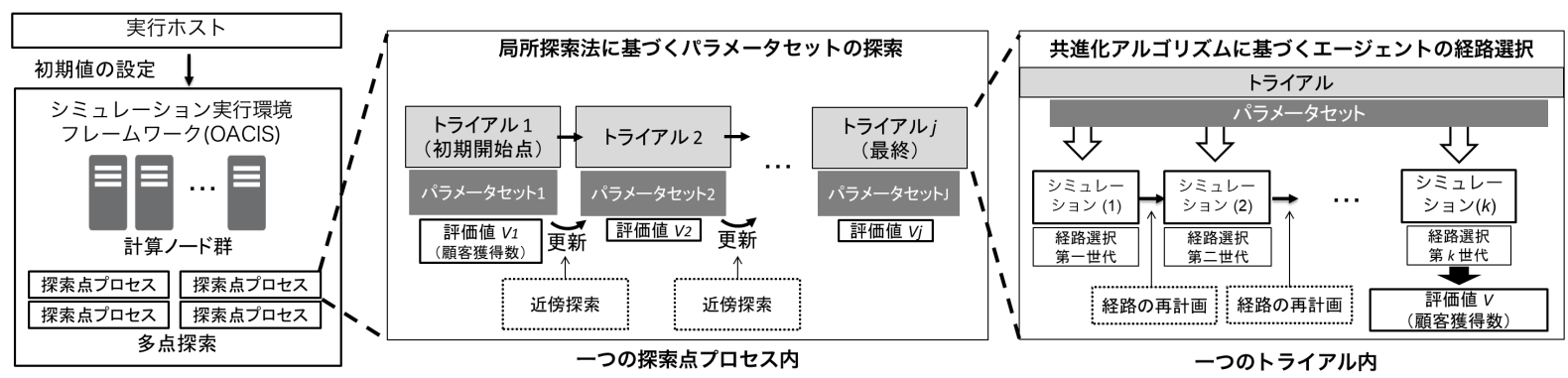

図 1 システムの概要

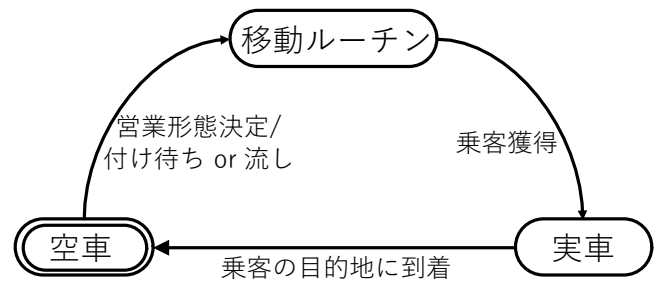

図 2 タクシーエージェントの状態遷移図

が確認できるとの知見に基づき，運転者は各々の戦略に 基づいて, 営業行動を行う地域（道路）を決定するもの である。

\section{$4 \cdot 1$ 運転者モデル}

本論文におけるタクシーの運転行動を, 先行研究 [Cheng 11, Grau 13, Takayama 11, 吉井 05] に従い, 定義する. タクシーの状態として，以下の二つを定義する.

実車 乗客を乗せて走行している状態

空車 乗客を乗せずに走行している状態

次に，タクシーの営業形態について定義する. 本論文 では, 営業中のタクシーが乗客獲得のために採る営業形 態として，以下の二つを定義する.

付け待ち営業 駅付近や繁華街近くの路上，またはタク

シ一乗り場において客待ちをし，そこで乗車する乗 客を獲得する営業形態

流し営業 道路を走行しながら乗客獲得を試みる営業形態

タクシーの営業形態については，タクシー無線やスマー トフォンからの依頼を受けて顧客を獲得する形態も存在 する．ただし，本論文では，先行研究 [Takayama 11] と 同様に, “付け待ち営業”と “流し営業”の二つの営業形 態の取り扱いに絞り込むこととする。

本論文では，文献 [金月 18] に従い，図 2 に示すよう な，比較的簡潔な状態遷移機械に基づくタクシー運転者 のモデルを想定する．タクシーは乗客の乗車状況に基づ く状態として空車と実車の二つの状態を採り，空車の状 態になると, 後述するタクシー運転者の運転者クラス, 現在時刻, および現在地の情報に基づいて, 次の営業形 態と共に，目的地を確率的に決定する.より具体的には， タクシー $i$ の状態が実車から空車に遷移すると, 次の営 業形態 $m_{i}$, および次の目的地 $l_{i, n e x t}$ を, 現在の時間帯 $t^{* 1}$, タクシーの走行の特性を表す運転車クラス $d_{i}$, およ び現在位置 $l_{i, \text { current }}$ をパラメータとして, 式 (1)に定義 する方策 $\pi_{i}$ に基づいて確率的に決定する.

$\pi_{i}\left(l_{i, \text { next }}, m_{i}, t, d_{i}, l_{i, \text { current }}\right)=\operatorname{Pr}\left(l_{i, \text { next }}, m_{i} \mid t, d_{i}, l_{i, \text { current }}\right)$

付け待ち営業を採ることになった場合, 運転者クラス に基づいて決定される付け待ち場所を目的地として移動 し，そこで乗客の乗車を待つ。ここでは，付け待ち場所 に到着後, 任意の待機時間経過後に乗客を獲得し, 実車 の状態に遷移する. タクシーエージェントは, シミュレー ション期間中, 図 2 に基づいた走行を継続的に行う. 本 論文では，図 2 に基づく走行プロセスにおける運転者の 個性を，1）空車時の付け待ち営業/流し営業の比率，お よび 2 ) 営業地域の選択傾向によって与えることとする.

i. 空車時の付け待ち営業/流し営業の比率

プローブデータを基に, 空車時における営業戦略の確 率的選択を行う。より具体的には, 各々の営業戦略に基 づく乗客の獲得割合を, 付け待ち営業, または流し営業 のいずれの営業戦略を採るかを規定する確率として割り 当てる。これにより, 営業戦略の選択傾向に関する運転 者の性質をエージェントに実装することができる.

ii. 経時的な変化を伴う営業地域の選択

また, タクシー運転者は, 経時的に変化するいわば“営 業のテリトリー”を持つと仮定し，モデル化を行う。具体 的には, 1 ) 京都市域を, タクシーが営業のテリトリー とし得る複数の地域に分類 (図 3) し，2）主な営業地域 に基づいてタクシー（運転者）の分類を行い, そして 3 ) 空車時の行き先を決定する確率パラメータを最尤推定に より計算して各々の分類に与える, という手続きでモデ ル化を行う.

\section{$4 \cdot 2$ タクシー運転手の分類とパラメータの設定}

タクシーを，どの地域で営業を行う傾向があるかを基 に分類する．具体的には以下の手続きを実施する.

(1) タクシー運転者ごとに, クラスタリングによって 得られた各地域における乗客獲得数を積算し, 正規 化することで, 各地域に関する乗客獲得率（各地域

*1 本論文では, シミュレーション時間を 1 時間ごとに区切り, これを時間帯とする. 
タクシーの運転者クラスが各地域で顧客を獲得する割合

\begin{tabular}{r||r|r|r|r|r|r|r|r|r}
\multicolumn{1}{c||}{} & \multicolumn{10}{c}{ 運転者クラス ID } \\
\cline { 2 - 10 } & 0 & 1 & 2 & 3 & 4 & 5 & 6 & 7 & 8 \\
\hline 地域 ID 0 & 0.22 & 0.39 & 0.37 & 0.28 & 0.29 & 0.37 & 0.31 & 0.27 & 0.42 \\
地域 ID 1 & 0.14 & 0.10 & 0.14 & 0.18 & 0.17 & 0.21 & 0.14 & 0.11 & 0.16 \\
地域 ID 2 & 0.06 & 0.13 & 0.19 & 0.08 & 0.08 & 0.13 & 0.12 & 0.18 & 0.09 \\
地域 ID 3 & 0.04 & 0.26 & 0.13 & 0.16 & 0.06 & 0.10 & 0.09 & 0.08 & 0.10 \\
地域 ID 4 & 0.10 & 0.02 & 0.03 & 0.07 & 0.20 & 0.09 & 0.13 & 0.03 & 0.04 \\
地域 ID 5 & 0.02 & 0.02 & 0.07 & 0.04 & 0.03 & 0.03 & 0.06 & 0.21 & 0.02 \\
地域 ID 6 & 0.01 & 0.05 & 0.03 & 0.05 & 0.01 & 0.02 & 0.02 & 0.01 & 0.03 \\
地域 ID 7 & 0.20 & 0.00 & 0.00 & 0.00 & 0.05 & 0.00 & 0.01 & 0.00 & 0.00 \\
地域 ID 8 & 0.02 & 0.01 & 0.01 & 0.04 & 0.02 & 0.02 & 0.02 & 0.01 & 0.09 \\
地域 ID 9 & 0.01 & 0.00 & 0.00 & 0.02 & 0.01 & 0.01 & 0.04 & 0.01 & 0.00 \\
地域 ID 10 & 0.00 & 0.00 & 0.01 & 0.01 & 0.00 & 0.00 & 0.01 & 0.08 & 0.00 \\
地域 ID 11 & 0.02 & 0.00 & 0.00 & 0.00 & 0.01 & 0.00 & 0.00 & 0.00 & 0.00 \\
地域 ID 12 & 0.04 & 0.00 & 0.01 & 0.01 & 0.04 & 0.01 & 0.02 & 0.01 & 0.02 \\
地域 ID 13 & 0.08 & 0.00 & 0.00 & 0.01 & 0.03 & 0.00 & 0.01 & 0.00 & 0.00 \\
その他の地域 & 0.04 & 0.01 & 0.01 & 0.06 & 0.01 & 0.01 & 0.02 & 0.01 & 0.01
\end{tabular}

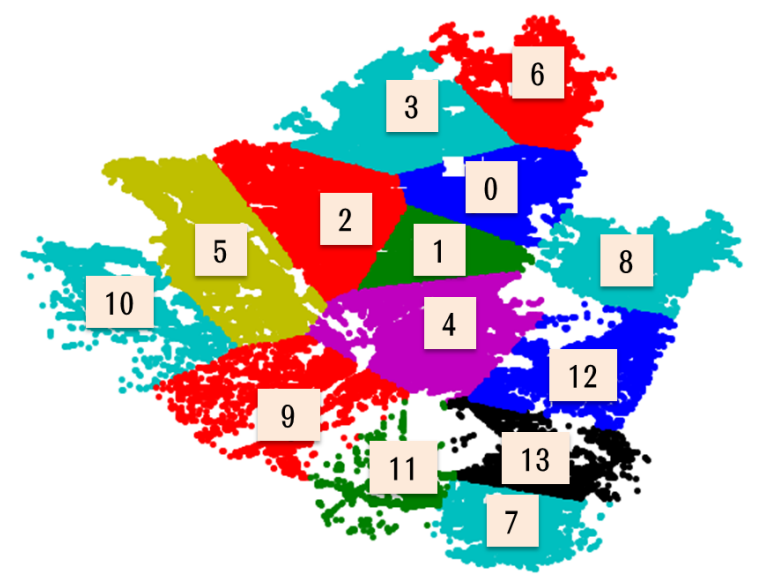

図 3 営業地域の分類: 図中番号は地域 ID を示す.

ID での顧客獲得回数を全地域での顧客獲得回数で 割ったもの）を算出する.

（2）乗客獲得率を特徵量としてクラスタリングを行い, タクシー運転者の分類を得る．運転者の適切な分類 数は未知であるため, 本論文では, クラスター数の 設定が不要な Affinity propagation [Frey 07] を用い てクラスタリングを行う.

クラスタリングの結果, 主たる営業地域に関して異なる 傾向を示す 9 個のクラスに分類された．表 1 は, 各クラ スに分類されたタクシー運転者の割合, および各クラス に分類されたタクシーの, 各地域での乗客獲得率を示し ている. また, 表 2 は各地域の営業行動について示す.

図 4 は，表 1 に示した各クラスに分類されたタクシー に関して, 乗客の獲得数を可視化したものであり, 左上図 が運転者クラス ID0 に対応する。ここでは，京都市全域 を, 1 辺の経緯度を 10 秒とした矩形で区切り, 矩形に対 応する区域ごとに獲得乗客数を積算して, 擬似色（デー タの大小をグレーの濃淡スケールに置き換え, さらに色 付けしたもの）を用いて獲得乗客数の多寡を表現してい る.ここでは, 運転者クラス内ごとに獲得乗客数を暖色
（高い獲得割合）から寒色（低い獲得割合）への変化に対 応付けている．本図から，クラスによって乗客を獲得す る地域の広がりや，ピークを示す地点に相違があり，異 なる営業傾向を抽出できていることを示している.

\section{$4 \cdot 3$ エージェントの目的地の決定}

空車から実車へと変化した場合にはプローブデータか ら抽出した顧客の需要に基づいた次の目的地（道路）の決 定，実車から空車へと変化した場合には運転者モデルの 方策に基づいた次の目的地 $l_{i, n e x t}$ と営業形態 $m_{i}$ の決定 が行われる．運転者クラス $d$ に分類される空車タクシー $i$ の目的地と営業形態を決定する方策 $\pi_{i}$ は，現在の時間 帯 $t$ と運転者の分類された運転者クラス $d_{i}$ と現在位置 $l_{i, \text { current }}$ から $4 \cdot 1$ 節に基づいて確率的に決定される.

実装上では，ノードとリンクの接続関係で表現される 道路ネットワークのうち，リンクをエージェントの現在位 置 $l_{i, \text { current }}$ や目的地 $l_{i, n e x t}$ として扱う. さらに, プロー ブデータの分析で得られたすべてのトリップ起点とトリッ プ終点は各点の最近傍の道路リンクに紐付ける．次の目 的地 $l_{i, n e x t}$ は実データにおいて顧客獲得履歴があった地 点の最近傍のリンクの位置を示すことになる．すなわち， タクシーの方策 $\pi_{i}$ の挙動について，本シミュレータでの 実装は, タクシーエージェントの現在位置 $l_{i, \text { current }}$ の最 近傍のリンクを入力の一つとして, 実データから次の顧 客を拾ったリンクを次の目的地リンクの候補として抽出 したあと，最尤推定によりそのリンクのうち一つを確率 的に選出し, 次の目的地 $l_{i, n e x t}$ とする.

\section{$4 \cdot 4$ 大規模交通シミュレータ}

機能レベルで個別化した車両エージェントを実現する ため，車両の挙動を細粒度で表現するモデルを利用可能 かつスケーラビリティを備えたシミュレーション基盤が 必要となる．筆者らは，大規模マルチエージェントシミュ レーションツールキット MATSim [Balmer 09] を利用し て，割り当てられた OD を基に走行経路を決定し，その 経路上を, 個々の運転行動モデルに基づいて走行する多数 のエージェントの振る舞いを計算可能な交通シミュレー タ MATSim-K を構築している [服部 10, Nakajima 12]. 本シミュレータにおけるエージェントの経路選択と道路 ネットワークについて，次のように設定する.

i. 経路探索

本論文におけるエージェントの経路選択は, 文献 [Balmer 09]に従って，最小経路探索に基づく共進化アルゴリズ ムを適用する。これは，シミュレーションを繰り返すご とに旅行時間の長いエージェントの経路を再計画するも のであり，観測データと近似した経路になるまでシミュ レーションを繰り返すものである．ここでは，センサス データから得られた京都市の中心の幹線道路を通る道路 交通量に最も近づく回数まで試行を行う．1) 走行経路決 定，2) 割り当てられた OD 間の走行，3) 走行結果の評価 


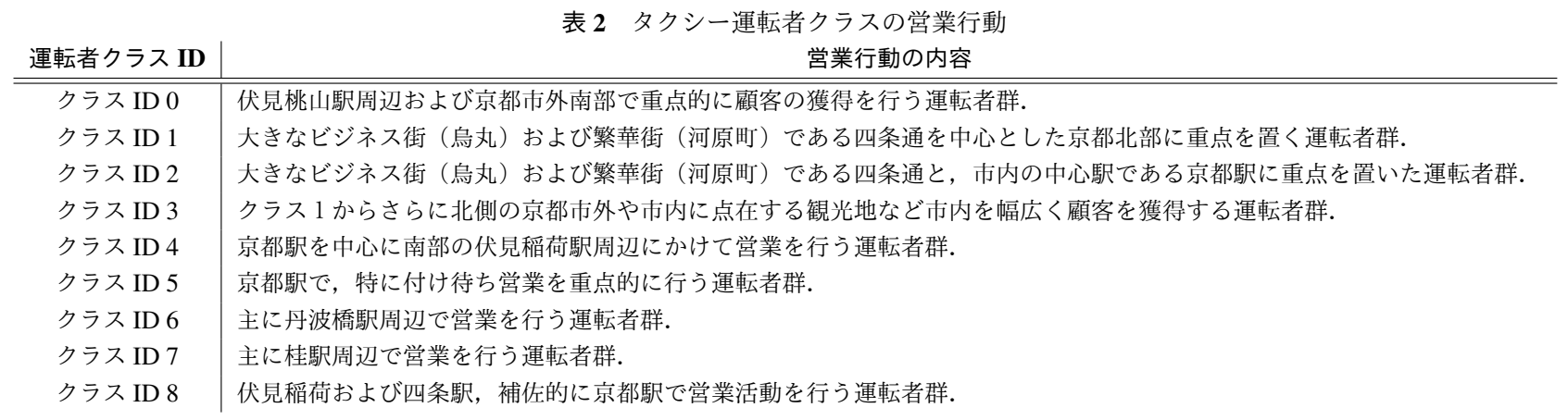

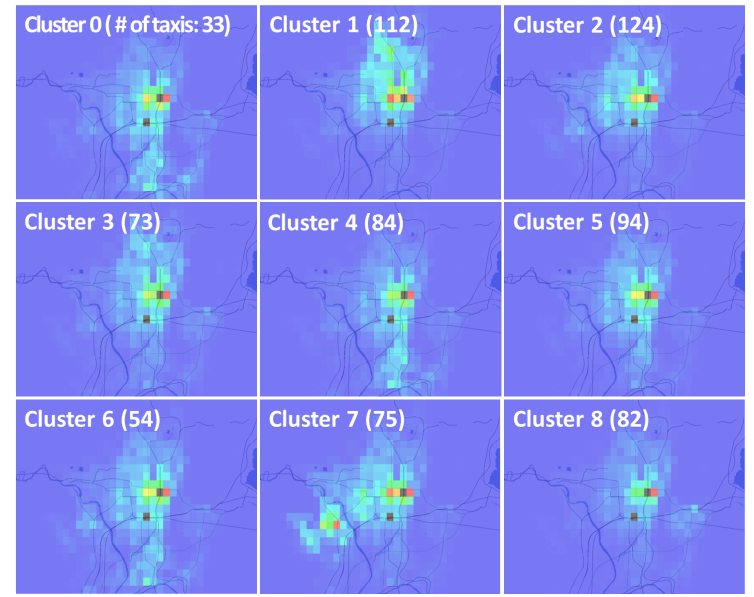

(a) 各運転者クラスごとの可視化

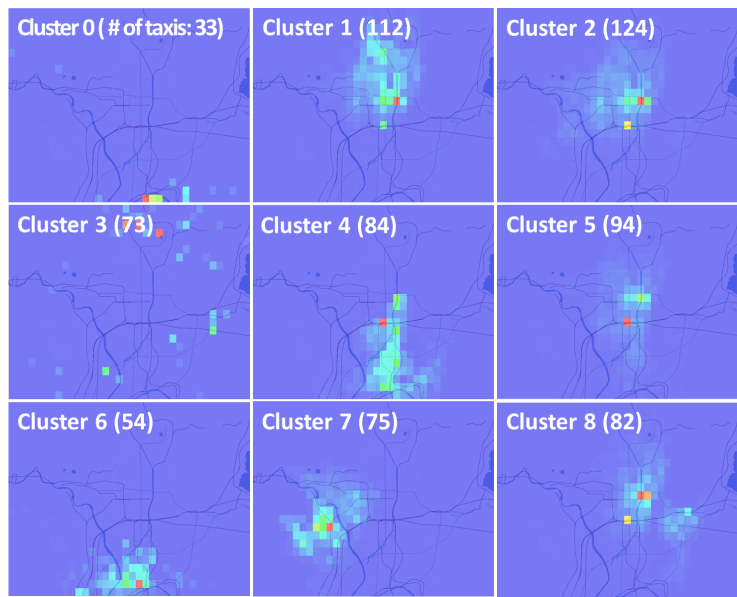

(b) 左図と全体平均との差分（偏差）

図 4 運転者クラスごとの乗客獲得地域: 赤 (多い) $\Leftrightarrow$ 青 (少ない)

（各道路区間の平均走行時間計算）から成り，この反復に よって各道路区間の走行時間を継続的に更新し，適当な 交通流の生成を行う。なお，走行経路の変更をするエー ジェント数は全体の $10 \%$ と設定している.

ii. 道路ネットワーク

道路ネットワークはゼンリン社から提供された複数車 線や上り下りの区別, 中央分離帯, 長さの情報が付随し たものを用いた。ただし，実験では道路上の信号を排し た環境で行った。これは，個々の信号機に対して素朴な 制御方式を設定することを仮定しても，隣接する信号機 の切り替え制御のタイミングを考慮せざるを得ず，都市 規模におけるシミュレーションに不具合を生じさせない タイミングの信号制御モデルの構築は非常に困難となる ためである．信号の有無が本論文の目的であるモデルの 性質の調査に関して挙動を極端に変えるものではないた め，信号制御に関しては本論文がカバーすべき内容を超 えるものとして，今回はシミュレーション環境に信号を 取り入れない.

\section{5 シミュレーション実行環境フレームワーク}

パラメータ探索のシミュレーション実行環境フレーム ワークとして, 理化学研究所計算科学研究機構で開発さ れている OACIS[Murase 14] を用いる. OACIS は，分 析や実験パラメータの生成および実行を，API を通して
実行することが可能である. 図 1 で示すように, 初期值 の各タクシークラスの台数パラメータと実行コマンドを OACIS を用いて計算ノード群に ssh 経由で配信し, 実行 結果をデータベースに保存する.

\section{5. 実験}

\section{$5 \cdot 1$ 設定}

本実験では，基本的な機能を実装した 200,000 台の一 般車両エージェントと, 各バス停の発着時間に基づいて 走行する 667 台のバスエージェント, および 7990 台の タクシーエージェントを用いた。高度で複雑なモデルを 一遍に取り入れることは相互の関連性を複雑にし，その 影響の効果について観測が難しくなる。本論文が目的と する個性の有無によるモデルの性質の違いの検証のため, 本実験ではタクシーのモデルのみ精緻化したものを用い ることとした。

タクシーの営業場所は, 早朝や夜間帯には駅や繁華街 に偏りやすい，そこで本実験では，より運転者間での挙 動に差異の出やすい平日の 10 時から 12 時のシミュレー ションを行う. エージェント数に関して, バスについて は, 発着時刻から推定可能な台数である. すなわち, バス は，実際の車両数にほぼ近似した台数となる．タクシー に関しては，分析に用いたプローブデータは 1 事業者に よる提供データに留まり，京都市を走るすべての車両の 
走行データではない. そこで, 図 4 で示した各タクシー運 転者クラスの台数比率を維持しながら，プローブデータ における主要道路の交通流量と交通センサスデータの比 較により, 京都市の主要道路におけるタクシーの流量に 近似する車両数を，事前の試行に基づいて推測した．結 果として本論文では，プローブデータに含まれる車両数 の 10 倍のタクシーエージェント 7990 台を用いてシミュ レーションを行い，そのうち京都市内の道路のみを走行 する 5500 台を車両台数のパラメータとして考慮するこ ととした。一般車両に関しては，センサスデータを参照 し設定した地域間 OD 表に基づいてエージェントを発生 させ, 京都市の主要道路における流量が近似するように, 事前の試行に基づいて一般車両台数を設定した. 200,000 台のエージェントは，任意の時点における走行中の車両 の総数ではなく, シミュレーション時間内に一度でも生 じた車両の総数であり, 短区間・短時間内に発生した車 両も含まれる。ここでは, 本論文で設定した程度の数が あれば京都市の主要道路における交通流の実態を十分再 現可能であるとして, シミュレーションを行った。 また， タクシーに関して, 行動特性を組み込んだ 9 の運転者ク ラス $d$ の各々のエージェント数はプローブデータによる 解析結果の分布に準じた。計算機環境は，図 1 における 1 計算ホスト当たり Intel(R) Xeon(R) CPU E5-2690 v3 $2.90 \mathrm{GHz}$ を $2 \mathrm{CPU}$ 搭載した 24 コア 48 スレッド，メモ リ $512 \mathrm{~GB}$ のものを用いており, 図 1 におけるトライア ル内の一つのシミュレーションをおよそ 20 分で実行可 能である. 本実験では, 2 台の計算ホスト上で, ホスト ごとに 25 のシミュレーションを同時実行させることで, 多点探索の探索点を全 50 点, すなわち，50 並列の探索 点プロセスを実行する. 探索パラメータは, 表 1 で示し た九つの運転者クラスの各エージェント数 $p$ であり, 一 つのパラメータセット $P$ は運転者クラス 0 から 8 までの 九つのパラメータ $p_{0}, p_{1}, \ldots, p_{8}$ で構成される. 初期の 探索点はランダムに決定する. 各エージェントモデルは, 4 章で定義した運転行動を行う。

\section{$5 \cdot 2$ 結果}

\section{$\S 1$ 多点探索}

シミュレーションの実行例を図 5 に示す。 また，一般 車両やタクシーに関する経路選択の共進化アルゴリズム による結果を図 6 に示す。ここでは, 近傍幅 $\delta$ を 50 と設 定した. 世代数が 9 世代以降では, 大きな改善が見られ ず，前世代よりも悪化することもあったため，20 世代で 打ち切った。 さらに, タクシーの顧客獲得回数が最も多 い四条通り周辺道路に関して, シミュレーションデータ と平成 22 年度に観測された京都市センサスデータを比 較して, 断面交通流量の差が最小となる值を求め, 図 1 における共進化アルゴリズムの世代数に関して， $k=11$ での評価值を用いることとした。

本条件下における全 50 点の多点局所探索法のパラメー

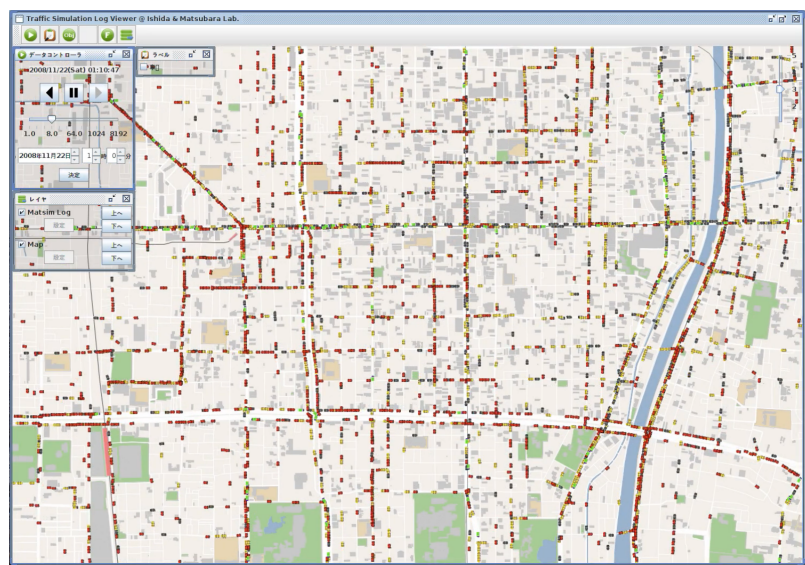

図 5 交通シミュレータ MATSim-K の実行例: 京都市中心街周辺部 をシミュレートした可視化結果. 色付けされたアイコンで各 車両エージェントが道路上をアニメーションにより走行して いる. 一般車両が赤, バスが緑, 空車タクシーが黒, 実車夕 クシーが黄として色付けされる.

タ探索過程のうち, 評価值である顧客獲得回数が上位 10 点と下位 10 点となった探索点の評価值のトライアル数を 変えた場合の 50 トライアルまでの推移について, 図 7 に 示す. 本論文での条件では, 最大顧客獲得回数がおよそ 15500 回の顧客を獲得できる機会を得る結果となり，パ ラメータセットの組み合わせにより評価值はおよそ 1000 回の差異が出る結果となった。ここで, 100 回のランダ ムシードを変えたシミュレーションを行い，各解に関し てランダムネスの検証を行ったところ, 結果に最大 \pm 168 回の差異が生じた。ランダムネスの影響により，順位の 変動が起きる可能性があるものの，パラメータの違いが 及ぼす影響に比べて小さいと結論付けられる. 15 トライ アルまで大きく改善が進んだ一方で，40 世代目からはこ のランダムネスの影響を上回る大きな改善が見られなく なったことから，50トライアルにて探索を終了し，解候 補の選定を行った。また，探索点の数と最大の顧客獲得 回数の関係について図 8 に示す. 図 8 は, 図 7 で示した 結果のときに，探索点数の増減による最大顧客獲得回数 の期待值を示す. 探索点がおよそ 15 点までは大きな上 昇を見せたが，それ以上の探索点の数の増加は, 最大顧 客獲得の増加には寄与するものの，上昇幅は小さくなっ た. 50 点以上の探索点数を増加しても，ランダムネスの 影響に比べて最大顧客獲得回数に与える影響は小さいと 考えられる. また, 各探索点の最終評価值について, タ クシーごとの 1 時間当たりの顧客輸送回数について割合 の平均を示したものを図 9 に示す。本図は顧客を目的地 までシミュレーション時間内に運ぶことのできた回数の 分布を示す. 本シミュレーションでは, 時間当たり 1,2 回顧客を輸送したタクシーの割合が大きく，少量の顧客 獲得が多いタクシーエージェントがあるなど分布の偏り は確認できなかった。 よって，今回の適用では全体最適 化によって個々のタクシーが大幅な不利益を被るケース 


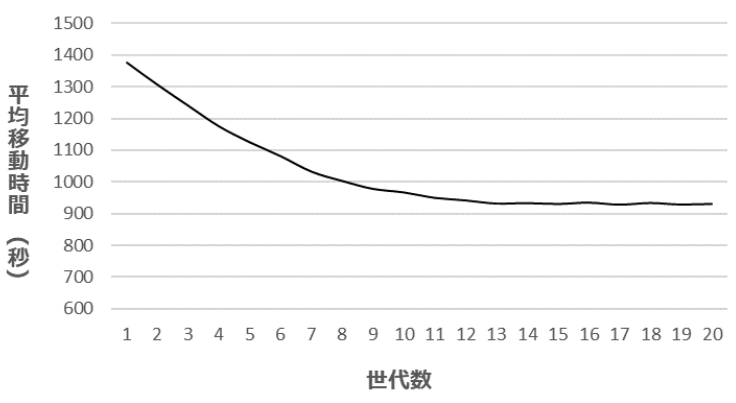

図 6 世代数と平均移動時間の関係

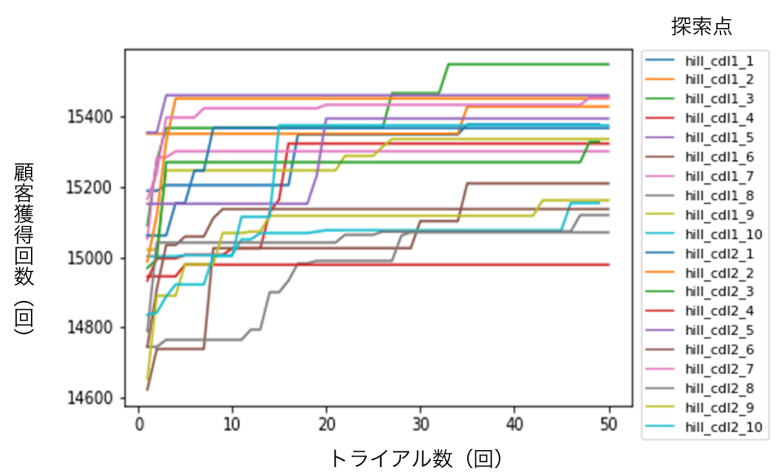

図 7 各探索点の最大評価值の推移 (全 50 探索点のうち上位 10 点 および下位 10 点)

は少ないと考えられる．本論文は最大顧客獲得回数のみ を導くことが主たる目的ではないものの，図７で得た結 果が解候補を導くため必要なトライアル数や探索点数を 満たせているものとして, 各解のファインチューニング と分析および考察を行った。

\section{§2 パラメータセットのクラスタリング}

$5 \cdot 2 \cdot 1$ 節で得られた局所解の 50 のパラメータセット に Affinity propagationによるクラスタリングを適用し， 三つのクラスに分類することができた．表 3 に示すのは 三つのクラス群から, 各クラスで最も評価值の高いパラ メータセットを抽出したものである.

\section{$\S 3$ ファインチューニング}

三つの解候補それぞれについて，ファインチューニン グの検証を行った. ファインチューニングについては, 得 られた三つの解候補に関してさらに近傍幅 $\delta$ を 10 として 350 回の局所探索を行い，顧客獲得回数に平均 138 回の 改善が見られた。しかしランダムネスによる影響を考慮 すると，ファインチューニングの効果は限定的であった。

\section{$\S 4$ 分析および考察}

表 3 に示す解候補に関して, 各運転者クラスの台数の 偏りから表 2 と合わせ，戦略の違いを考察した．第一解 候補は，運転者クラス 1 や運転者クラス 2 に属する行動

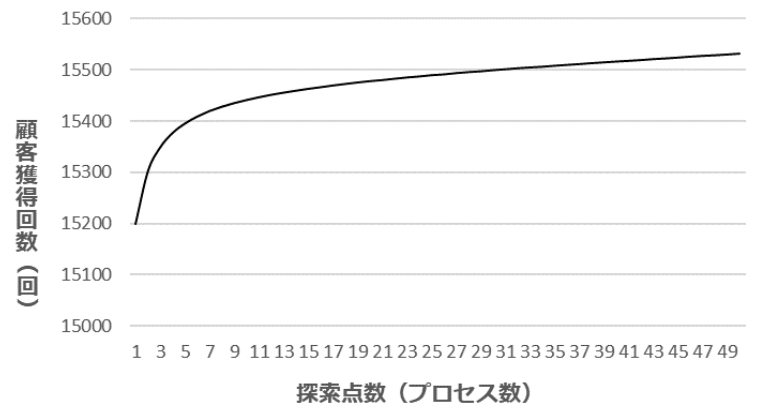

図 8 探索点数と最大顧客獲得回数の関係

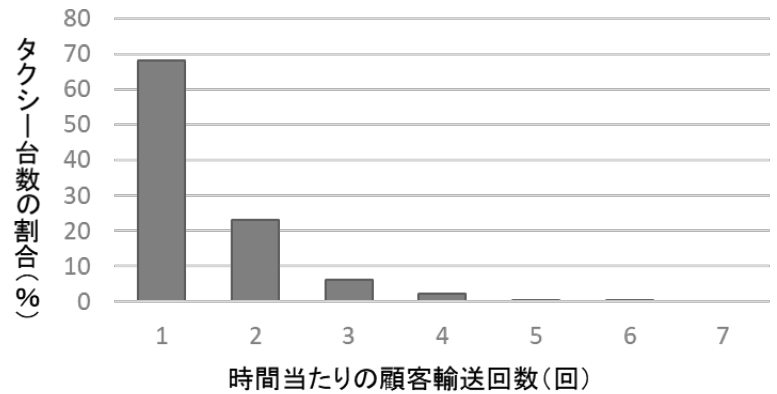

図 91 時間当たりの各タクシーの顧客輸送回数の割合（全探索点 の最終評価值の平均)

を行うタクシーエージェントが多く, 四条通りと京都北 を中心に，付け待ちと流しをバランス良く行う戦略配置 となっている．第二解候補は，運転者クラス 2 , 次いで運 転者クラス 4 に属するタクシーエージェントが多く, 四 条通りの付け待ちおよび伏見稲荷駅周辺での営業を主戦 略に行うタクシーの営業行動となっていた。また，第三 解候補は, 運転者クラス 5 が多く, 京都駅の付け待ちを 主戦略に行うタクシーの営業行動となった。得られた解 の候補がそれぞれのシナリオを有しており，本論文が目 的とするシミュレーションを利用した複数の改善シナリ オを提案できていることが示唆される.

本論文では, タクシーの運転行動の個性に着眼し, ク ラスタリングによってそれぞれの個別化を行った。本論 文での提案手法は, 広い解空間を持つシミュレーション においても, 現実世界における様々な問題に対して, 改 善可能なシナリオの提案を抽出し, 複数の回答案を提案 することが可能である．また，本件で扱った問題に固執せ ず，その他のシミュレーション環境においても適用可能 であると考えられる，ただし本論文で述べた結果は，様々 な仮定の上に成り立ち, 現場に即適用できるものではな い.たとえば，付け待ち場所の混雑の考慮などステーク ホルダの要求するすべての要件を満たしているとは言え ないため，段階的にモデルを精錬することが求められる. 
表 3 パラメータ群の準最適解の候補

\begin{tabular}{l||c||c|c|c|c|c|c|c|c|c}
\hline \hline & 雇客獲得回数 (回) & クラス 0 & クラス 1 & クラス 2 & クラス 3 & クラス 4 & クラス 5 & クラス 6 & クラス 7 & クラス 8 \\
\hline 第一解候補 & 15547 & 312 & 801 & 1772 & 48 & 575 & 582 & 480 & 581 & 349 \\
\hline 第二解候補 & 15459 & 92 & 42 & 2913 & 141 & 1165 & 359 & 215 & 28 & 545 \\
\hline 第三解候補 & 15452 & 559 & 42 & 723 & 564 & 241 & 1849 & 227 & 645 & 650 \\
\hline \hline
\end{tabular}

\section{6. 終わりに}

本論文では，MASim に基づくタクシーを例題とした 準最適な営業戦略の探索に関して，クラスタ計算基盤下 を用いた複数の最適な営業戦略行動シナリオ提案手法に ついて述べた。メタヒューリスティックアルゴリズムを用 いてパラメータ探索を行い, 複数の局所最適解を抽出し た. 最後に, それぞれの解の分析を行い, 営業戦略に関 する複数の改善シナリオの提案を行った. 本論文の提案 手法は, 広い解空間を持ち, 解の性質が不明である問題 において, 有用に㗢くと考えられる. また, クラスタ計算 機を増やして多点探索箇所を増やせば，より高速に解を 得ることが可能である. 本論文で提案した手法を用いる ことで, 新たな施策評価を精緻に行うことが期待される. バスも含めた公共交通の充実が, 都市内の人の移動にど のような影響を及ぼすのか, タクシーやバスの台数や配 置について様々なシナリオを事前に検証し, 効果的な施 策の立案を支援することが可能である. また， タクシー に焦点を当てた場合, タクシー事業者の利潤を最大化す るためのタクシーの配車戦略の検討を支援する基盤とな ることが考えられる. 今後の課題として, 目的関数や制 約条件に関するさらなる検討を行う必要がある.たとえ ば，目的関数を報酬の最大化とすれば，各タクシー運転 者の報酬の偏りと最適化方法や制約について議論が可能 となる. また, より複雑な問題では多くの入力パラメー タを探索対象とした検証が必要であることから, 計算速 度の向上や探索にかかる計算量を削減する必要がある.

\section{謝辞}

本研究は, 文部科学省ポスト「京」萌芽的課題 2「複 数の社会経済現象の相互作用のモデル構築とその応用研 究」の支援を受けて実施したものです.

\section{$\diamond$ 参 考 文 献 $\diamond$}

[Balmer 09] Balmer, M., Rieser, M., Meister, K., Charypar, D., Lefebvre, N., Nagel, K., and Axhausen, K.: MATSim-T: Architecture and simulation times (2009)

[Bischoff 16] Bischoff, J. and Maciejewski, M.: Simulation of citywide replacement of private cars with autonomous taxis in Berlin, Procedia Computer Science, Vol. 83, pp. 237-244 (2016)

[Cheng 11] Cheng, S.-F. and Nguyen, T. D.: TaxiSim: A multiagent simulation platform for evaluating taxi Fleet Operations, in Web Intelligence, Vol. 2, pp. 14-21 (2011)

[Frey 07] Frey, B. J. and Dueck, D.: Clustering by passing messages between data points, Science, Vol. 315, No. 5814, pp. 972-976 (2007)

[Grau 13] Grau, J. M. S., Romeu, M. A. E., Mitsakis, E., and Stamos, I.: Agent based modeling for simulation of taxi services, Jour- nal of Traffic and Logistics Engineering, Vol. 1, pp. 159-163 (2013)

[Murase 14] Murase, Y., Uchitane, T., and Ito, N.: A tool for parameter-space explorations, Physics Procedia, Vol. 57, pp. 73-76 (2014)

[Nakajima 12] Nakajima, Y., Yamane, S., and Hattori, H.: Multimodel based simulation platform for urban traffic simulation, in Principles and Practice of Multi-Agent Systems, Vol. 7057 of Lecture Notes in Computer Science, pp. 228-241, Springer Berlin Heidelberg (2012)

[Shen 17] Shen, J., Liu, X., and Chen, M.: Discovering spatial and temporal patterns from taxi-based Floating Car Data: A case study from Nanjing, GIScience \& Remote Sensing, Vol. 54, No. 5, pp. 617638 (2017)

[Sun 16] Sun, H. and McIntosh, S.: Big data mobile services for New York City taxi riders and drivers, in 2016 IEEE International Conference on Mobile Services (MS), pp. 57-64 (2016)

[Takayama 11] Takayama, T., Matsumoto, K., Kumagai, A., Sato, N., and Murata, Y.: Waiting/cruising location recommendation for efficient taxi business, International Journal of System Applications, Engineering \& Development, Vol. 5, pp. 224-236 (2011)

[Wu 17] Wu, H., Fan, H., and Wu, S.: Exploring spatiotemporal patterns of long-distance taxi rides in Shanghai, ISPRS International Journal of Geo-Information, Vol. 6, No. 11, pp. 339-354 (2017)

[吉井 05] 吉井 稔雄, 藤田 大輔, 北村 隆一 : プローブデータを用 いた空車タクシー挙動分析, 第 31 回土木計画学研究講演集, 第 31 巻, pp. 200-204 (2005)

[金月 18] 金月 寛彰, 服部宏充: プローブデータを用いたタクシー の個別営業戦略のモデル化と交通シミュレーションへの適用, 情 報処理学会論文誌, Vol. 59, No. 5, pp. 1373-1385 (2018)

[小柴 14] 小柴等, 野田 五十樹, 山下 倫央, 中島 秀之: 実環境を 考慮したバスシミュレータ SAVSQUID による実運用に向けた デマンドバスの評価, コンピュータソフトウェア, Vol. 31, No. 3, pp. 141-155 (2014)

[服部 10] 服部 宏充, 中島 悠, 加藤 整, 石田 亨, 山根 昇平 : 大規模 マルチエージェント交通シミュレーション, 自動車技術, Vol. 64, No. 3, pp. 38-44 (2010)

〔担当委員 : 櫻井 祐子〕

2018 年 10 月 12 日 受理

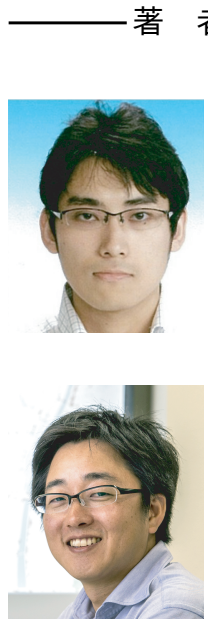

者 紹 介

\section{金月 寛彰(正会員)}

2018 年京都大学大学院情報学研究科社会情報学専攻博士 後期課程単位認定退学. 現在，株式会社富士通研究所人工 知能研究所. マルチエージェントシミュレーション，デー タマイニング，機械学習に興味を持つ。

\section{服部 宏充(正会員)}

2004 年名古屋工業大学大学院工学研究科博士後期課程修 了. 博士 (工学). 同年日本学術振興会特別研究員 (PD). リ バプール大学、マサチューセッツ工科大学客員研究員, 京 都大学大学院情報学研究科助教を経 $て, 2014$ 年立命館大学 情報理工学部准教授、マルチエージェントシミュレーショ ン，人間行動モデリング，社会システムデザインに興味を 持つ. 